\title{
THE DISPOSAL OF RADIOAGTIVE WASTE IN ICE SHEETS
}

\author{
By K. Philberth \\ (Peter-Rosegger-Strasse 6, D 8oz I Puchheim, Germany)
}

\begin{abstract}
The waste containers should be retrievable for a few centuries until further research has solved all problems and ${ }^{90} \mathrm{Sr}$ and ${ }^{137} \mathrm{Cs}$ have decayed to less than $0.1 \%$. Safe and fairly cheap retrievability can be guaranteed without container mooring. The paper presents an example: The high-level waste of the whole world for the next 30 years could be put into $3 \times 10^{7}$ spherical containers with $0.2 \mathrm{~m}$ radius and disposed of in an area with $15 \mathrm{~km}$ radius and a depth range of $20-100 \mathrm{~m}$ under the surface of either the Antarctic or the Greenland ice sheet. The deposit does not affect the stability of the sheet. Even the most upsetting natural ice-sheet instabilities and/or climatic changes could not cause radioactive contamination.

RÉsumé. Sur le rejet des déchets radioactifs dans les calottes glaciaires. Les conteneurs de déchets devraient être récupérables pendant quelques siècles jusqu'à ce que de futures recherches aient résolu tous les problèmes et que le ${ }^{95} \mathrm{Sr}$ et ${ }^{137} \mathrm{Cs}$ aient abaissé leur activité à moins de $0,1 \%$. Une récupérabilité sûre et fort bon marché peut être garantie sans amarrage des conteneurs. Ce travail présente un exemple: les déchets les plus actifs du monde entier pour les 30 prochaines années ont mis dans $3 \times 10^{7}$ conteneurs sphériques, avec un rayon de $0,2 \mathrm{~m}$ et disposés sur une surface de $15 \mathrm{~km}$ de rayon et une profondeur de 20 à $100 \mathrm{~m}$ sous la surface de l'Antarctique et du Groenland. Le dépôt n'affecte pas la stabilité de la calotte. Même les instabilités naturelles les plus imprévues dans les calottes de glace et par les changements climatiques ne pourraient provoquer une contamination radioactive.

Zusammenfassung. Über die Beseitigung radioaktiver Abfälle in Eis-schilden. Die Abfall-Behälter sollen einige Jahrhunderte lang rückgewinnbar sein — bis weitere Forschung alle Probleme gelöst hat und ${ }^{\circ} \mathrm{Sr}$ und ${ }^{137} \mathrm{Cs}$ auf weniger als $0, \mathrm{I} \%$ zerfallen sind. Sichere und relativ billige Rückgewinnung können auch ohne Anseilung der Behälter gewährleistet werden. Dieser Aufsatz bringt ein Beispiel: Der innerhalb der nächsten $3^{\circ}$ Jahre anfallende hochaktive Abfall der ganzen Welt wird in $3 \times 10^{7}$ kugelförmige Behälter mit $0,2 \mathrm{~m}$ Radius gefüllt und auf einer Fläche mit $15 \mathrm{~km}$ Radius und in einem Tiefenbereich von $20-100 \mathrm{~m}$ unter der Oberfläche des Antarktischen oder Grönländischen Eisschildes deponiert. Die Beseitigung beeinträchtigt die Stabilität deз Schildes nicht. Selbst die umwälzendsten Instabilitäten des Eisschildes und/oder klimatischen Änderungen können nicht zu radioaktiver Verseuchung führen.
\end{abstract}

\section{INTRODUGTION}

Two decades have passed since B. Philberth first proposed putting radioactive fission products from nuclear reactors on the ice of Antarctica or Greenland (Philberth, B., I956, I958, I959[a], [b], I96o, I96I; Haefeli, I96r). The first resolution on this proposal was that of the I.C.S.I. of I.A.H.S. at Chamonix, 24 September 1958 (Dolgushin, 1959). In recent years there has been much argument about this idea (Zeller and others, I973; Weertman and others, I973; Weertman, in press; Schneider and Platt, r974; U.S. Atomic Energy Commission, 1974; Bull, 1975; resolutions of C.P.R. (May 1973), I.C.S.I. (May 1973) and S.C.A.R. (September 1974): see [Robin], 1975, on the meeting of September 1974 and K. Philberth, I976[a], [b]).

There have been different understandings of what "radioactive high-level waste" is. B. Philberth and I propose disposal of the fission products which are "waste" in the proper sense of the word. Some others, however, have discussed the disposal of more or less all reactor output isotopes: fission products plus actinides. Plutonium-239, for example, is very toxic and has a half-life of 24000 years. Both factors make it dangerous for ultimate storage. It is, however, a most valuable fissionable fuel. Therefore it will be recycled, not disposed of. For more details compare Section VII.

Previous publications on the disposal of radioactive waste in ice sheets have neglected or underestimated two important points: The retrievability of the waste containers and the avoidance of environmental contamination even in the case of natural or man-made catastrophic surges of the whole ice sheet.

With regard to these two points, this paper proposes that the disposal of radioactive waste in the ice sheets of Antarctica or Greenland should be restricted to a relatively small area and a relatively small depth. A circular area with a radius of $15 \mathrm{~km}$ and a depth range between $20 \mathrm{~m}$ and $100 \mathrm{~m}$ is sufficient to store the world's high-level waste of the next three decades. 
Figure I demonstrates how tiny this area is. In Greenland the deposit site should be relatively near to the ice divide. In Antarctica the ice velocities are slower and the ice divide is perhaps not the best deposit site (Zeller and others, 1973).
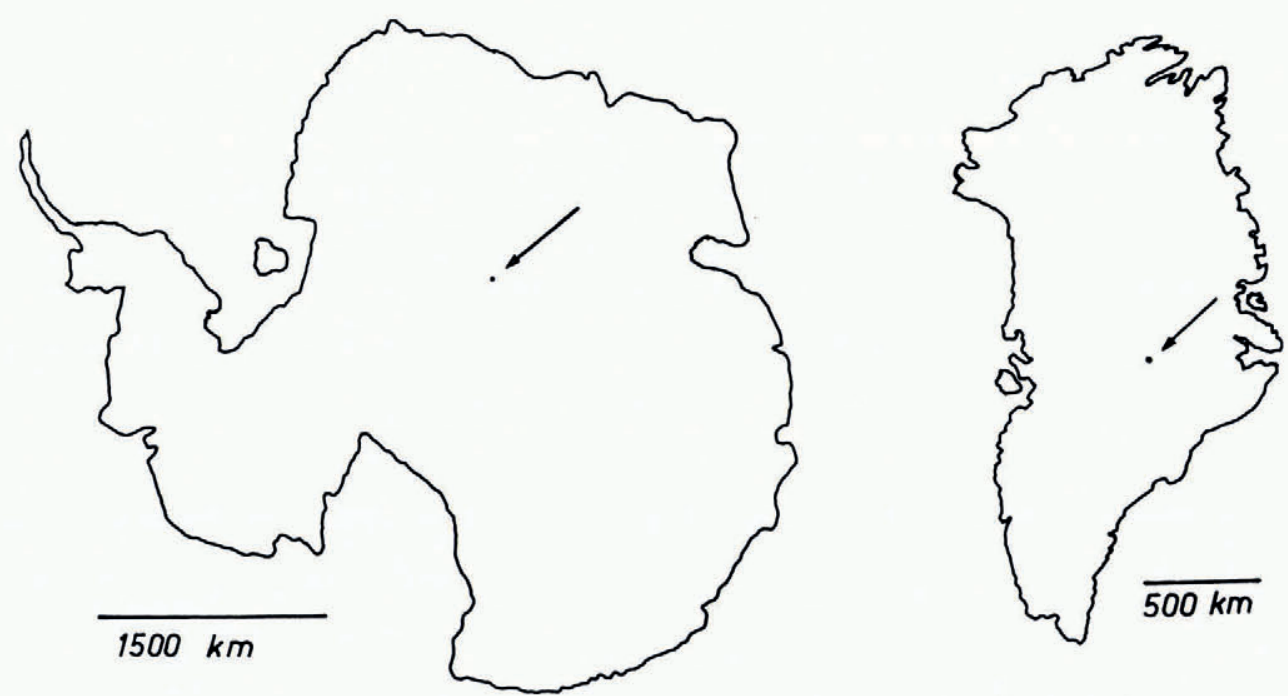

Fig. I. The tiny spot represents the size of the proposed deposit area with radius $r=I_{5} \mathrm{~km}$.

\section{Retrievability of the WASte containers}

Storage of the waste under never-ending direct human control is not the best solution. "The ideal would be that each generation takes all the trouble and care necessary for the safe storage of the materials it has produced, leaving no responsibility to future generations" (Dyne, 1975). It is not however certain whether all future generations will have sufficient goodwill and technical knowledge to keep our wastes safe (K. Philberth, 1976[a]).

The retrieval of the waste containers from the ultimate storage site should be possible; at least for a few centuries, until further research has had sufficient time for a complete understanding of all the problems involved. Moreover, after 300 years the most dangerous fission products ${ }^{90} \mathrm{Sr}$ and ${ }^{137} \mathrm{Cs}$ have decayed to about $0.1 \%$.

But retrieval of the containers should not be too simple in order to exclude misuse by ignorant or criminal people. By means of modern radar detectors and mining equipment the waste containers could be detected and retrieved from a shallow firn or ice volume with $15 \mathrm{~km}$ radius and roo or even $200 \mathrm{~m}$ depth. Such retrieval would not be dangerous or too expensive.

The average distance of the containers from one another would be in the order of $10 \mathrm{~m}$. The containers could be picked up from a conventional pit and tunnel system. Down to a depth of 100 or $200 \mathrm{~m}$ such a system will withstand hydrostatic pressure sufficiently long, even without additional arrangements against ice flow. If appropriate containers are used, their radiation is so small that they can be handled without much special precaution, cf. Section VII.

Indeed, according to the suggestions of this paper, within a few centuries the containers will be no deeper than $100 \mathrm{~m}$ or $\mathrm{I} 50 \mathrm{~m}$. After the melting down of the containers in the firn has come to a standstill-cf. Section VI-it is only the accumulation which increases their depth below the current surface. This increase is of the order of $5 \mathrm{~m}$ per century for Antarctica, and about $25 \mathrm{~m}$ per century for Greenland. 


\section{ICE INSTABILITY AND CLIMATIC CHANGES-GENERAL ASPEGTS}

It is fairly probable that the Antarctic and Greenland ice sheets will survive some tenthousands of years more, and it is extremely probable that they will survive some further thousands of years. We have good reason to hope so, because the total melting of both ice sheets would raise sea-level $80 \mathrm{~m}$. Nevertheless, we are not entitled to risk any unexpected ice melting bringing about a man-made radioactive catastrophe for our descendants.

It has been demonstrated that appropriate storage of radioactive waste on large areas (B. Philberth, I959[b]) or on small areas (K. Philberth, I976[b]) does not affect the stability of the ice sheet. This argument is also valid for the disposal suggested in this paper, but the stability could be menaced by natural influences. On a much smaller scale, the so-called ice surges give an example of instabilities which are caused by a feed-back mechanism: increasing ice velocity causes increase of the frictional heat and thus of the temperature and the fluiditywhich in its turn results in a further increase of the ice velocity (Lliboutry, 1968; K. Philberth, in press).

At present it cannot be absolutely excluded that large parts of the Antarctic or the bulk of the Greenland ice sheet could fall into such a feed-back instability. Theoretically such feed-back instabilities are well understood. What we need is more knowledge of the mechanical properties of the ice and more knowledge about the "boundary conditions" of the sheets, i.e. their surface and bedrock topology and their thermal and rheological conditions (Budd and others, I97I; K. Philberth, in press). We may expect that in ten or twenty years a precise prediction about ice-sheet stability will be made for a time-interval of at least a thousand years.

There is one decisive uncertainty factor: climate. Any unknown natural or man-made cause could change the climate decisively from tomorrow. Climatic changes have two influences on the stability of ice sheets; both have a long time constant.

The first influence is the alteration of the temperature and thus of the fluidity of the ice laycrs. But it is the layers near the bed which are decisive for the stability of the ice sheet. The superficial climatic temperature changes reach these bottom layers by heat transport and thermal diffusion. It takes thousands of years until these processes can affect the stability (Robin, 1970).

The second influence is the alteration of the accumulation or ablation rate. This results in a change in the thickness of the sheet and the shear stresses in the ice. Equal lowering of the whole ice-sheet surface reduces the shear stresses and thus increases stability. Unequal raising or lowering of the surface could augment the surface slope and thus decrease the stability. Under reasonable assumptions on the climatic change it takes hundreds of years until the ice thickness variation has significant impact on the ice-sheet stability. Modern computer techniques allow us to calculate in advance whether or not any climate-induced ice-thickness changes could provoke instability.

\section{Safety aspegts for EXtreme ice Surge or climatic Ghange conditions}

The ultimate storage of radioactive waste has to be absolutely safe. We must not rely exclusively on our prediction of the stability of the ice sheet, however precise and trustworthy it may be. Let us regard the most unfavourable case: that immediately after the disposal of the whole waste the total ice sheet becomes unstable. In this case it would be best to retrieve the containers-cf. Section II. But even if nothing is done, the possibility of a radioactive catastrophe will be excluded, under three conditions: (a) The waste containers must not be corroded by melt water and/or the waste inside the containers has to be insoluble, e.g. fused in glass. (b) The waste must not contain significant quantities of toxic isotopes with half lives longer than some hundreds of years. (c) The instability must not reduce the ice-sheet thickness too much. 
A sudden instability of the sheet would produce sufficient heat to increase the ice temperature significantly and to provoke a gigantic ice surge. The worst situation would be that all ice becomes temperate and that the ice sheet, having lost most of its mechanical resistance, would lower its surface down to a level which is determined by the surrounding mountain chains. Our example of Section VI refers to Greenland conditions, where the mountain chain in the east and in the west would prevent the ice surface from a sudden lowering down to less than $\mathrm{r} \mathrm{km}$ above sea-level. In Antarctica, the topological and rheological conditions are more complicated, but not less appropriate.

In our example (cf. Section VI) the total decay energy is $50 \mathrm{~W} \times \mathrm{I} a+5^{\circ} \mathrm{W} \times 4^{2} \mathrm{a}=$ 2 I $50 \mathrm{~W}$ a per container. In temperate ice, containers with this energy and $0.2 \mathrm{~m}$ radius melt a channel not much longer than half a kilometre. That means that even in temperate ice with a reduced ice thickness of $I \mathrm{~km}$, the containers stay several hundred metres above the bedrock. Thirty years after the dumping of the containers, the length of their melt channel in temperate ice is only a few hundred metres.

The worst imaginable surge of the whole sheet would neither bring the containers near the bottom nor near the edge of the ice sheet. It would increase the radius of the container area from an original $15 \mathrm{~km}$ to not more than $30 \mathrm{~km}$. The containers would not reach the sea, even if such a fantastic surge were to involve a dislocation of the ice divide by Ioo or $200 \mathrm{~km}$.

What is the minimum time for an ice sheet to melt away? Rapid melting could be caused by extreme climatic changes and/or by a gigantic ice surge which brings the surface below the firn limit. Under most unfavourable conditions a time span of the order of thousand years could be sufficient to melt the Greenland and - in the case of upsetting astronomical events-perhaps even the Antarctic ice sheet (Weertman, 1964). Such an event would cause a flood catastrophe-but not a radioactive catastrophe.

Let us imagine that the surface of the storage site is suddenly affected by an ablation rate of say a few metres per year. The surface lowers and approaches those containers which had come to the standstill. But in the range of $\mathrm{I} \mathrm{m}$ below the melting surface the ice is nearly temperate. And as soon as this range reaches a container which still has thermal power, this container will start to melt ice again. Thus it will keep near the surface, a part of it may even break the surface, but radioactive melting and pressure melting will not allow the container as a whole to pass the surface. Thus it is easy to recognize the containers and to pick them up, but they cannot migrate to any undefined place. When all the ice has melted, the containers stand undamaged on the bedrock or the moraine-until they are picked up or their radioactive isotopes have decayed.

The result of such semi-quantitative calculations is that within many thousands of years the radioactive waste cannot reach the open environment - even in the case of most improbable and most upsetting natural catastrophes. Increased glaciological knowledge and improved computer techniques will yield more precise data.

\section{The temperature increase in a steady-STAte IGe Sheet}

The general equation for the temperature $T$ in a moving homogeneous and isotropic medium is:

$$
x \nabla^{2} T-\mathbf{v} \cdot \operatorname{grad} T-\partial T / \partial t=0,
$$

where $x$ is the diffusivity, the temperature dependence of which is neglected, $\mathbf{v}$ is the velocity, and $t$ is the time. The temperature field $T$ of the undisturbed ice sheet is a solution of Equation (I) (Philberth and Federer, I971; Robin, 1976). The heat produced by the waste causes a temperature increase $\Delta T$ which is also a solution. The sum of both solutions $T+\Delta T$ is again a solution; it is the temperature field of the waste-container-charged ice sheet. 
Our idealized calculation of $\Delta T$ will assume that the area of the ice sheet under consideration is stationary and that the temporal and local changes of its accumulation rate and the slope of its surface and its bedrock are negligible. Furthermore it will be based on the blockflow model (Nye, I95I ; Robin, I955), where the vertical velocity $\left|v_{h}\right|$ is equal to the accumulation rate $A$, multiplied with the ratio $h / H$ of the height $h$ above bedrock to the total height $H$ of the ice sheet. Finally, the horizontal components of $\operatorname{grad}(\Delta T)$ will be neglected. Under these assumptions Equation (I) becomes:

$$
x \partial^{2}(\Delta T) / \partial h^{2}+h(A / H) \partial(\Delta T) / \partial h-\partial(\Delta T) / \partial t=0 .
$$

This paper deals with the case when $\Delta z_{0}$, the mean thickness of the vertical heat distribution soon after the dumping period, is relatively small; for example $\leqslant \mathrm{roo} \mathrm{m}$. Already a thousand years after the dumping the heat has diffused more than $300 \mathrm{~m}$ in both directions from the central plane. Consequently, for $t \geqslant \mathrm{I}$ ooo years we get a good approximation of the real $\Delta T$ profile if we neglect $\Delta z_{0}$. For $\Delta z_{0} \rightarrow 0$, Equation (2) yields a solution of the form

$$
\Delta T=[2 x(f-\mathrm{I}) \pi / k]^{-\frac{1}{2}} \exp -\left[2 x(f-\mathrm{I}) /\left(f z^{2} k\right)\right]^{-1} \int_{-\infty}^{+\infty} \Delta T_{0} \mathrm{~d} z,
$$

where $\Delta T_{0}$ is the temperature increase 200 years after the dumping (when the waste has nearly decayed but the ice nearly not expanded), $z$ is the height above the middle plane of the heat distribution, $k=A / H$, and $f=\exp (2 k t)$.

Equation (3) is the exact solution for the idealized case that at $t=0$ a quantity of heat has been spread uniformly in the horizontal plane $z=0$ of a horizontally and vertically unlimited ice mass, the vertical distances of which contract by the factor $\mathrm{I} / \sqrt{ } f=\exp (-k t)$. This Equation (3) yields the same values for $\Delta T$ as are obtained by the Fourier method using equation (4) of K. Philberth (1972).

The real ice sheet, however, is limited by its surface and by the bedrock. For the sake of simplicity we ignore the upper surface and neglect the heat flux through the bedrock. This simplified model yields exaggerated values of $\Delta T$. Its temperature increase $\Delta T$ is the sum of two partial functions according to Equation (3), the first of which represents the temperature profile from the real container layer, the second of which represents the temperature profile from a fictitious container layer which is $2 h$ below the real one.

Figure 2 shows the result for a waste deposit which in the dumping period has the radius $r=15 \mathrm{~km}$, the mean depth of the extrapolated initial heat distribution is $100 \mathrm{~m}$, and $\Delta z_{0} \leqslant$ Ioo $\mathrm{m}$. In accordance with a recent paper (K. Philberth, I976[b]) this corresponds to a residual waste energy of $2 \times 1^{0^{18}} \mathrm{~W} \mathrm{~s}$, resulting from say 30 years electric power output of $\mathrm{IO}^{12} \mathrm{~W}$, to an accumulation rate $A$ of $0.25 \mathrm{~m}$ of ice/year and a total ice thickness $H$ of $3 \mathrm{~km}$ (Greenland conditions). The horizontal dilatation rate of the deposit area is equal to the dilatation rate shown in figure $\mathrm{I}$ of $\mathrm{K}$. Philberth (1976[b]).

\section{The Melting DOWN OF THE WASte CONTAiners IN THE FIRN}

The waste containers melt themselves down through the firn as long as their thermal power exceeds the conductive heat flux. The problems involved are complex; we have to content ourselves with approximations.

The heat conductivity of the firn is proportional to the square of the firn density $\rho$ (Abels, Kondrat'yeva). The density $\rho$ is proportional to $\left(\zeta+\zeta_{\mathrm{s}}\right)^{\frac{1}{4}}$, where $\zeta$ is the depth of the container $(H-h)$ and $\zeta_{\mathrm{s}}$ is a constant (F. Brandenberger, A. Roch, R. Schneider, A. Renaud; see de Quervain, I969, p. I04a, I 78-79). Of course this relation loses its validity at the depth $\zeta_{1}$ where the density of pure ice is reached. 


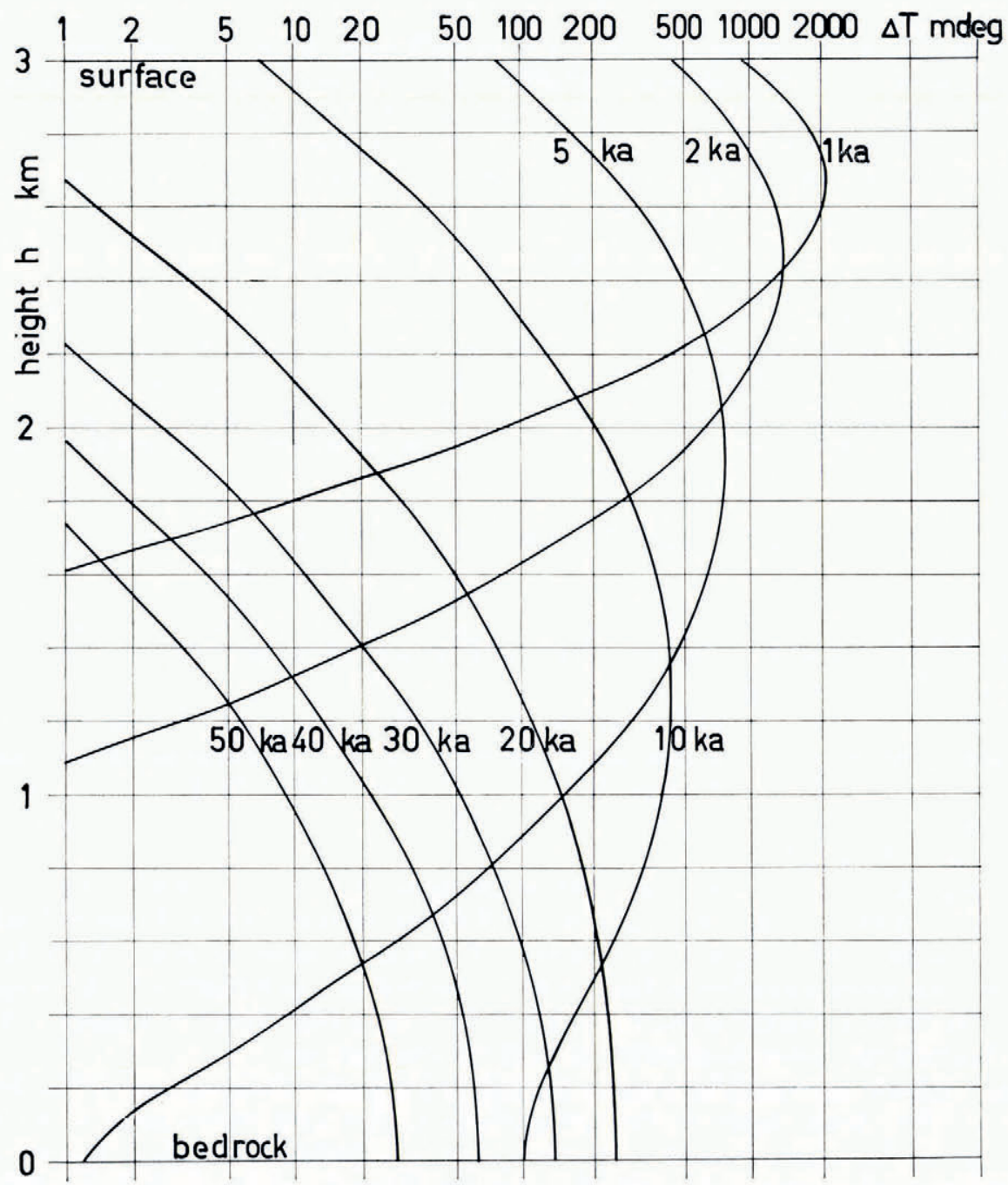

Fig. 2. Idealized profiles of the waste-induced temperature increase $\Delta T$ from 1 ooo until 50 ooo years after dumping; $A=0.25$ m of ice/a.

The thermal power $\mathcal{N}$ of the waste can be calculated as if the total waste consisted of two isotopes only: isotope A with the mean life $\tau=\mathrm{I}$ year and isotope B with the mean life $\sigma=42$ years (K. Philberth, $1976[\mathrm{~b}])$.

The preceding relations suggest the following equation for the downward velocity $v=\mathrm{d} \zeta / \mathrm{d} t \geqslant 0$ of a container:

$$
v=v_{\mathrm{sn}}\left[\mathcal{N}_{0 \tau} \exp (-t / \tau)+\mathcal{N}_{0 \sigma} \exp (-t / \sigma)-|\bar{T}|\left(n_{0}+n_{\mathrm{I}} \delta^{\frac{1}{2}}\right)\right] \delta^{-\frac{1}{4}},
$$

where $v_{\mathrm{sp}}$ is the "specific velocity", depending on the container dimensions, $\mathcal{N}_{\mathrm{o} \tau}$ the initial power of the isotope with mean-life $\tau=\mathrm{I}$ year, $\mathcal{N}_{\mathrm{o} \sigma}$ the initial power of the isotope with mean-life $\sigma=42$ years, $\bar{T}=T+\Delta T$ the ambient temperature of the firn, referred to the melting point, $n_{0}, n_{\mathrm{I}}$ constants depending on the container dimensions, and $\delta$ a "depth parameter", defined as $\left(\zeta+\zeta_{\mathrm{s}}\right) / \zeta_{\mathrm{i}}$. 
For Greenland (de Quervain, I969) and for spherical containers with $0.2 \mathrm{~m}$ radius it is reasonable to put $v_{\mathrm{sp}}=0.3 \mathrm{~m} \mathrm{a}^{-1} \mathrm{~W}^{-1} ; \quad n_{\mathrm{o}}=\mathrm{I} \mathrm{W} / \mathrm{deg} ; \quad n_{\mathrm{I}}=3 \mathrm{~W} / \mathrm{deg} ; \quad \zeta_{\mathrm{s}}=2.5 \mathrm{~m}$; $\zeta_{1}=130 \mathrm{~m}$.

Figure 3 shows $\zeta$ as a function of $t$. The initial depth $\zeta_{0}$ is assumed to be zero-an assumption which is somewhat unrealistic but simple. Figure 3 is based on the integration of Equation (4) with the above-mentioned values and with $\mathcal{N}_{0 \tau}=5^{\circ} \mathrm{W}$ and $\mathcal{N}_{\mathrm{o} \sigma}=5^{\circ} \mathrm{W}$. These initial powers correspond to 4 years interim-stored fission products, produced by the fission of $1.5 \mathrm{~kg}$ uranium, plutonium or thorium. Ten years interim storage would reduce the initial powers to $\mathcal{N}_{0 \tau}<\mathrm{I} \mathrm{W}$ and $\mathcal{N}_{0 \sigma} \approx 45 \mathrm{~W}$. The melt-down depth $\zeta$ is determined by many factors: interim storage and concentration of the waste, size and shape, interior and superficial heat conduction, initial depth, and possible mooring of the containers, etc. Figure 3 represents just one possibility.

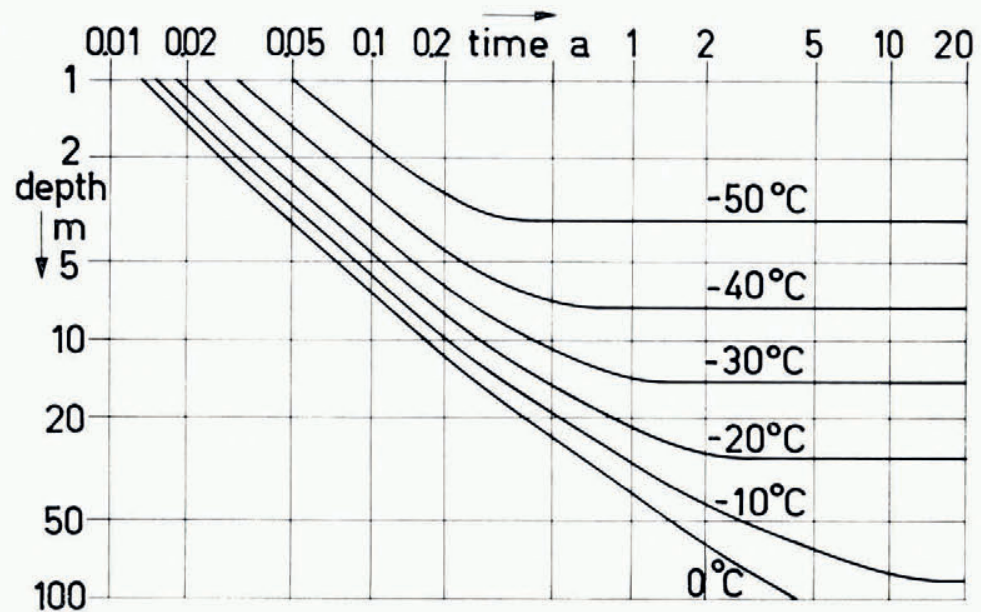

Fig. 3. Melting down of containers with $0.2 \mathrm{~m}$ radius and initially having $5^{\circ} \mathrm{W}$ with $I$ year plus $5^{\circ} \mathrm{W}$ with $4^{2}$ years mean life; from $-50^{\circ} \mathrm{C}$ to $0^{\circ} \mathrm{C}$ ambient firn temperature $T+\Delta T$.

The stand-still depth of every container depends on the ambient temperature $\bar{T}=T+\Delta T$ (Fig. 3), where $T$ is the undisturbed temperature and $\Delta T$ is the mean temperature increase. But in the first centuries, $\Delta T$ in its turn depends on the mean depth of all containers together. Thus the vertical distribution of the containers is self-controlling. In our example $\left(2 \times 10^{18}\right.$ W s of energy distributed among $3 \times 10^{7}$ containers; $\pi(15 \mathrm{~km})^{2} \approx 700 \mathrm{~km}$ deposit area), $\int \Delta T_{0} \mathrm{~d} z$ of Equation (3) is $\mathrm{I} .5 \mathrm{deg} \mathrm{km}$. With $\Delta z_{0}=50 \mathrm{~m}$, the ambient temperature would reach about $-50+30=-20^{\circ} \mathrm{C}$ for Antarctica and $-30+30=0^{\circ} \mathrm{C}$ for Greenland conditions. However, according to Figure 3 the latter case is unreal, because approaching $-10^{\circ} \mathrm{C}$ or an even higher ambient temperature would make the containers melt down to a depth which corresponds to more than $\Delta z_{0}=50 \mathrm{~m}$. This control effect together with thermal diffusion prevents the mean temperature from coming near to the melting point. The temperature should be supervised, e.g. by non-retrievable thermal probes (K. Philberth, г962, г976[c]).

\section{HALF LifE OF THE ISOTOPES-ShIELding OF THE GONTAINERS}

${ }^{90} \mathrm{Sr}$ and ${ }^{137} \mathrm{Cs}$ are the most burdensome fission products; both have half-lives of about 30 years. The quantities or energies of ${ }^{15} \mathrm{Sm}$ (half-life $\left.93 \mathrm{a}\right),{ }^{79} \mathrm{Se}\left(6.5 \times 10^{4} \mathrm{a}\right),{ }^{126} \mathrm{Sn}\left(10^{5} \mathrm{a}\right)$ and ${ }^{93} \mathrm{Zr}\left(\mathrm{I} .5 \times \mathrm{IO}^{6} \mathrm{a}\right)$ are extremely small; the energy and the toxicity of ${ }^{99} \mathrm{Tc}\left(2 \times 10^{5} \mathrm{a}\right)$ are 
small. The other long-lived fission-product isotopes have half lives of at least $2 \times 10^{6} \mathrm{a}$. The disintegration rate being the reciprocal of the half-life, these isotopes have very low activity (B. Philberth, I96I; Switzerland. Eidg. Amt für Energiewirtschaft, I976; Lewis, I972; Seelmann-Eggebert and others, I974; K. Philberth, I976[r], [b]).

Furthermore there are radioactive actinides which are formed in reactors by neutron absorption. The spectrum of these isotopes depends on the type of reactor and fuel. ${ }^{239} \mathrm{Pu}$ $\left(2.4 \times 10^{4} \mathrm{a}\right),{ }^{240} \mathrm{Pu}(6500 \mathrm{a})$ and ${ }^{241} \mathrm{Am}(433 \mathrm{a})$ are the most dangerous actinides. Plutonium has to be recovered from the waste - and it pays for itself, as ${ }^{239} \mathrm{Pu}$ is a very valuable reactor fuel. ${ }^{241} \mathrm{Am}$ should be eliminated or at least significantly reduced.

From different points of view (safety, economy, possibility of re-cycling) there is only one real solution to the reactor waste problem: To separate its isotopes and to treat each part in the most appropriate way. Isotopes, not waste, should be disposed of; modern trends aim in this direction.

For transportation the waste has to have shielding against its $\gamma$-radiation. After a few years interim storage the $\gamma$-radiation is produced mainly by ${ }^{144} \mathrm{Ce} /{ }^{144} \mathrm{Pr}$ (half-life $0.78 \mathrm{a}$ ), ${ }^{106} \mathrm{Ru} /{ }^{106} \mathrm{Rh}$ (I a), ${ }^{85} \mathrm{Kr}$ (I I a), ${ }^{137} \mathrm{Cs}$ (30 a), ${ }^{151} \mathrm{Sm}$ (93 a) and ${ }^{241} \mathrm{Am}$ (433 a). The $\gamma$-energy and the quantity of ${ }^{85} \mathrm{Kr}$ are small; the $\gamma$-energy of ${ }^{151} \mathrm{Sm}$ is very small; it is absorbed by several centimetres of lead shielding.

A container shielded with $10 \mathrm{~cm}$ of lead is sufficient for practical purposes. After a few years interim storage it reduces the radiation around a container with $\mathrm{I} .5 \mathrm{~kg}$ fissioned uranium or thorium to less than $0.3 \mathrm{R} / \mathrm{h}$ (= roentgen per hour); after more than io years interim storage-when the $\gamma$-radiation is predominantly determined by ${ }^{137} \mathrm{Cs}$ with its $\gamma$-energy of $0.662 \mathrm{MeV}$ - to less than o. I R/h. By present standards the permissible exposure time for a professional to $0 . \mathrm{I} \mathrm{R} / \mathrm{h} \gamma$-radiation is of the order of 50 hours per year. After 400 years the radiation beside such a container with $10 \mathrm{~cm}$ lead shielding is no more than the natural cosmic radiation.

The retrieval of the containers is simple if the shielding is a permanent part of the container. Spherical containers with a lead wall $0.1 \mathrm{~m}$ thick and with an outer radius of $0.2 \mathrm{~m}$ have a weight of $35^{\circ} \mathrm{kg}$; about $\$ 25^{\circ}$ have to be paid for its lead shielding. This is about $\mathrm{I} / \mathrm{I}$ ooo of the price for which the energy gained from the container's fissioned uranium $(\mathrm{r} .5 \mathrm{~kg})$ is sold.

\section{Acknowledgement}

I am obliged to the Swiss Eidg. Institut für Schnee- und Lawinenforschung where I was allowed to work on this paper; furthermore to Dr P. J. Dyne of Atomic Energy of Canada Limited and to Dr K. Goebel of CERN for detailed information on actinides and shielding problems.

\section{REFERENGES}

Budd, W. F., and others. I971. Derived physical characteristics of the Antarctic ice sheet, by W. F. Budd, D. Jenssen and U. Radok. ANARE Interim Reports, Series A (IV) Glaciology, Publication No. 20.

Bull, C. B. B. 1975. Radioactive waste disposal. Science, Vol. 189, No. 4203, p. 596-97, 658 .

Dolgushin, L. D. I959. Mezhdunarodnyy simpozium po fizike dvizheniya l'da v lednikakh [International symposium on the physics of ice movement in glaciers]. Izvestiya Akademii Nauk SSSR. Seriya Geograficheskaya, i959, No. i, p. I4 I-45.

Dyne, P. J. I975. AECL's responsibilities and programs for management of high level radioactive wastes. Pinawa, Manitoba, Whiteshell Nuclear Research Establishment. (Atomic Energy of Canada Limited, AECL-5I I I.)

Haefeli, R. 1951. Glaziologische Einführung zur Frage der Beseitigung radioaktiver Abfallstoffe in den grossen Eiskappen der Erde. Schweizerische Zeitschrift für Hydrologie, Vol. 23, Fasc. 1, p. 253-62. 
Lewis, W. B. 1972. Radioactive waste management in the long term. Chalk River, Ontario, Chalk River Nuclear Laboratories. (Atomic Energy of Canada Limited, AECL-4268.)

Lliboutry, L. A. 1968. Steady-state temperatures at the bottom of ice sheets and computation of the bottom ice flow law from the surface profile. Fournal of Glaciology, Vol. 7, No. 51, p. 363-76.

Nye, J. F. 1951. The flow of glaciers and ice-sheets as a problem in plasticity. Proceedings of the Royal Society of London, Ser. A, Vol. 207, No. 1091, p. 554-72.

Philberth, B. 1956. Beseitigung radioaktiver Abfallsubstanzen. Atomkern-Energie (München), I. Jahrg., Ht. I 1-12, p. $396-400$.

Philberth, B. 1958. Disposal of atomic fission products in Greenland or Antarctica. Union Géodésique et Géophysique Internationale. Association Internationale d'Hydrologie Scientifique. Symposium de Chamonix, I6-24 sept. 1958, p. 350. (Publication No. 47 de l'Association Internationale d'Hydrologie Scientifique.)

Philberth, B. I959[a]. Beseitigung radioaktiver Abfallsubstanzen in den Eiskappen der Erde. Atomkern-Energie (München), 4. Jahrg., Ht. 3, p. I $16-19$.

Philberth, B. I959[b]. Stockage des déchets atomiques dans les calottes glaciaires de la Terre. Comptes Rendus Hebdomadaires des Séances de l'Académie des Sciences (Paris), Tom. 248, No. 14, p. 2090-92.

Philberth, B. 1960. Discussion of advantages and disadvantages of radioactive waste disposal into geological structures. (In Disposal of radioactive wastes. II. Proceedings of the scientific conference on the disposal of radioactive wastes, ... held at the Oceanographic Museum in the Principality of Monaco, 16-21 November 1959. Vienna, International Atomic Energy Agency, p. 557.)

Philberth, B. 196r. Beseitigung radioaktiver Abfallsubstanzen in den Eiskappen der Erde. Schweizerische Zeitschrift für Hydrologie, Vol. 23, Fasc. I, p. $263-84$.

Philberth, K. 1962. Une méthode pour mesurer les témperatures à l'intérieur d'un inlandsis. Comptes Rendus Hebdomadaires des Séances de l'Académie des Sciences (Paris), Tom. 254, No. 22, p. $388 \mathrm{r}-83$.

Philberth, K. 1972. Factors influencing deep ice temperatures. Nature, Physical Science, Vol. 237, No. 72, p. 44-45.

Philberth, K. 1976[a]. Future regard to the atomic waste disposal problem. Fournal of Glaciology, Vol. 16, No. 74 , p. $277-78$.

Philberth, K. $1976[\mathrm{~b}]$. On the temperature response in ice sheets to radioactive waste deposits. Fournal of Glaciology, Vol. i6, No. 74, p. 89-98.

Philberth, K. $1976[\mathrm{c}]$. The thermal probe deep-drilling method by EGIG in 1968 at station Jarl-Joset, central Greenland. (In Splettstoesser, J. F., ed. Ice-core drilling. Proceedings of a symposium, University of Nebraska, Lincoln, 28-3o August 1974. Lincoln, London, University of Nebraska Press, p. 1 1 7-31.)

Philberth, K. In press. Die thermische Tiefbohrung in Station Jarl Joset und ihre theoretische Auswertung. Meddelelser om Grenland.

Philberth, K., and Federer, B. 1971. On the temperature profile and the age profile in the central part of cold ice sheets. Fournal of Glaciology, Vol. 10, No. 58, p. $3^{-1} 4$.

Quervain, M. R. de. 1969. Schneekundliche Arbeiten der Internationalen Glaziologischen Grönlandexpedition (Nivologie). Meddelelser om Gronland, Bd. 177, Nr. 4 .

Robin, G. de Q. 1955. Ice movement and temperature distribution in glaciers and ice sheets. Fournal of Glaciology, Vol. 2, No. 18, p. 523-32.

Robin, G. de Q. I 970 . Stability of ice sheets as deduced from deep temperature gradients. [Union Géodésique et Géophysique Internationale. Association Internationale d'Hydrologie Scientifique.] [International Council of Scientific Unions. Scientific Committee on Antarctic Research. International Association of Scientific Hydrology. Commission of Snow and Ice.] International Symposium on Antarctic Glaciological Exploration (ISAGE), Hanover, New Hampshire, U.S.A., 3-7 September 1963, p. I41-51. (Publication No. 86 [de 1'Association Internationale d'Hydrologie Scientifique].)

[Robin, G. de Q.] 1975. The disposal of radioactive wastes in the Antarctic ice sheet. Polar Record, Vol. 17, No. I 10, p. $578-79$.

Robin, G. de Q. 1976 . Reconciliation of temperature-depth profiles in polar ice sheets with past surface temperatures deduced from oxygen-isotope profiles. Fournal of Glaciology, Vol. 16, No. 74, p. 9-22.

Schneider, K. J., and Platt, A. M., ed. r 974 . High-level radioactive waste management alternatives. Vol. 3. Ice sheet disposal-sea bed disposal. Richland, Washington, Battelle Pacific Northwest Laboratories. (Report BNWL1900.) [Available from: National Technical Information Service, Springfield, Virginia 22 I 51.]

Seelmann-Eggebert, W., and others. 1974. Karlsruher Nuklidkarte, 4. Auflage, von W. Seelmann-Eggebert, G. Pfennig und $H$. Münzel. Karlsruhe, Gesellschaft für Kernforschung $\mathrm{mbH}$.

Switzerland. Eidg. Amt für Energiewirtschaft. 1976. Verordnung über den Strahlenschutz. CH 5303 Würenlingen, Eidg. Amt für Energiewirtschaft.

U.S. A tomic Energy Commission. 1974. High-level radioactive waste management alternatives. Oak Ridge, Tennessee, USAEG Technical Information Center. (Report WASH-1297.) [Available from: National Technical Information Service, Springfield, Virginia 22151.]

Weertman, J. I964. Rate of growth or shrinkage of nonequilibrium ice sheets. Fournal of Glaciology, Vol. 5, No. 38 , p. $145^{-} 5^{8}$.

Weertman, J. In press. Radioactive waste disposal in Antarctica. (Paper presented at Scientific Committee on Antarctic Research meeting, Cambridge, September i 974.)

Weertman, J., and others. 1973. Radioactive wastes on ice. Further discussion, [by] J. Wecrtman, J. Sibert, W. F. Weeks [and] J. Sternig. Bulletin of the Atomic Scientists, Vol. 29, No. 4, p. 2-3, 53-56. [Includes replies by E. J. Zeller, D. F. Saunders and E. E. Angino; cf. Zeller and others, 1973.]

Zeller, E. J., and others. 1973. Putting radioactive wastes on ice. A proposal for an international radionuclide depository in Antarctica, [by] E. J. Zeller, D. F. Saunders and E. E. Angino. Bulletin of the Atomic Scientists, Vol. 29 , No. 1, p. $4-9,50^{-} 5^{2}$. 


\section{DISGUSSION}

W. Goon: Would you please comment on the disadvantages of the method and on the problems of transportation?

K. Philberth: One disadvantage is that, compared with other geological formations, ice is relatively unstable and that it depends on climatic changes (compare question of $\mathrm{H}$. Röthlisberger). However, as pointed out in Sections III and IV of this paper, this disadvantage produces no safety hazard. Another disadvantage is that there are only two ice sheets which can be taken into account. If the politicians of the countries concerned say "no", the project cannot be realized. Furthermore, transportation is necessary. This transportation is sufficiently safe and cheap-but it has to be done. Putting the waste in a geological formation near the reactor requires no transportation. However, in this case, mankind has as many deposit sites as it has nuclear reactors. This is a large number. Such a distribution of the waste to many places means increased safety hazards.

B. Stauffer: Is the air transport of the radioactive waste to the interior of Antarctica not practically as risky as a transport by rocket to the sun?

Philberth: By present standards air transport is orders of magnitude safer than rocket transport to the sun - not to mention the very high cost of the latter method. And even if an accident should really happen, a single aircraft accident will not bring about environmental contamination, provided sufficient precautions (waste incorporated in glass and surrounded by metal walls) have been provided. Falling of waste containers from the outside into the atmosphere of the Earth, however, produces such a high frictional energy that it would be difficult to avoid destruction of the containers and contamination of the atmosphere. Furthermore, air transport is not the only possible means of transport to the Antarctic or Greenland ice sheets. Studies have been made on transport by ship plus vehicles (e.g. sledges with caterpillar tractors or subsurface railways).

R. LIsT: I am frightened by the prospects of having radioactive waste stored in ice sheets, and I do not want to have this meeting on record as accepting such proposals by default. Besides the safety aspects I also do not think that the projected scarcity of lead and steel in the early part of the third millenium would allow production of containers for a large fraction of the radioactive waste. (A method involving smaller amounts is not worth considering.)

Philberth: With regard to general reflections on the safety problem, please compare the statements of "I. Introduction" of my paper in the Burnaby symposium (K. Philberth, I $976[\mathrm{~b}]$, p. 89-9o). Dealing with waste disposal problems has nothing to do with promoting the use of nuclear energy. My brother Bernhard has emphasized that already in the preface to the reprints of his first paper on this subject (B. Philberth, I956). The use of waste containers with thick lead walls was just an example. There are other possibilities: For example, from a vehicle at the surface, the waste, incorporated in a body of glass and housed in a lead casing, could be lowered down into the firn, e.g. to a depth of $\mathrm{ro} \mathrm{m}$. Then the waste container body is released and the lead casing is drawn up again by means of a steel chain to which it is fixed.

O. Orheim: Different time periods have been proposed for the isolation of the radioactive waste in ice sheets. The period has been reduced from what we discussed a few years ago, therefore some glaciological objections have disappeared, yet presumably the usefulness of the disposal method has also been reduced. Making the time period short enough would perhaps remove all glaciological objections, and I would like to mention three non-glaciological objections, any one of which I believe is sufficient to prevent the method being applied on the Antarctic ice sheet. 
(I) The safety factor. Every year for the past twenty years there have been aircraft accidents in Antarctica, and these do not promise well for the very large flying programme proposed. Besides the hazards of the hostile Antarctic environment there are the dangers of transport by sea. It will be much safer to avoid these extra transportation hazards by locating the disposal site near the waste-producing site.

(2) The cost factor. The Battelle report (Schneider and Platt, 1974) concluded that icesheet disposal is much more costly than disposal in the earth; this will favour some variety of the latter.

(3) The political problem. The disposal of radioactive waste in Antarctica is specifically prohibited in the Antarctic Treaty, which will be in force at least until 1989. The prohibition could be lifted by unanimous agreement among the Treaty Nations, but although it is outside our competence to foresee the political future it seems most improbable that such an agreement could be reached.

Philberth: It is true that in recent years extremely long inclusion periods have been mentioned and that they had to be reduced. My brother and I had never advised reliance on such long inclusion times. For example, in his paper of 196 I (Philberth, B., I96I) my brother outlined the necessity of inclusion periods in the order of I ooo years.

(I) Air transport. Please compare my replies to the questions of W. Good and B. Stauffer.

(2) Cost factor. Safety is decisive, not cost-as long as the disposal costs range at a few per cent or less of the value of the energy produced. And the ice disposal method is under this cost limit (but not the rocket-to-the-sun method).

(3) Political problem. We are scientists and are responsible for the scientific and technical point of view. If the ice sheet method will prove to be not the best one - why trouble the politicians? If it does prove to be the best one- why then should we not hope to convince the politicians of the nations concerned? Greenland, which would be nearer and allow for cheaper and safer transport than Antarctica, is part of Denmark. If Danish scientists, assisted by scientists of other nations, come to the conviction that the Greenland ice sheet solution is the best one, absolutely safe for everybody, why should they not hope to convince their government? If they do, the Danish government could supervise the correct realization of the method and take royalties from the users of other countries.

H. RöthlisBerger: Why should ice be considered at all on a world-wide scale when there are much more stable geological bodies like salt and anhydrite deposits - even located in depressions with no water discharge to the ocean?

Philberth: In the present stage of research it is not yet possible to decide what the best solution of the waste disposal problem will finally be. We cannot just compare special features of one disposal project with those of another one. What has to be done is: to study each reasonable project as a whole, with all its specific hazards, advantages and disadvantages. Profound studies of the possible projects will require perhaps some ten or twenty years. We cannot afford to concentrate our studies on just one possibility - which later, when the waste problem has really become urgent, may prove to be unreliable. Let us use the next ten or twenty years to do detailed research on all reasonable possibilities. The U.S. Atomic Energy Agency has asked the Battelle Institute to work out a detailed report on four projects of waste disposal, the ice-sheet project being just one of them (cf. Schneider and Platt, 1974). 